University of Nebraska - Lincoln

DigitalCommons@University of Nebraska - Lincoln

1987

\title{
Mesodictyon, A New Fossil Genus of the Centric Diatom Family Thalassiosiraceae from the Miocene Chalk Hills Formation, Western Snake River Plain, Idaho
}

\author{
Edward Theriot \\ Great Lakes Research Division, University of Michigan, Ann Arbor, Michigan 48109 \\ J. Platt Bradbury \\ USGS
}

Follow this and additional works at: https://digitalcommons.unl.edu/usgsstaffpub

Part of the Earth Sciences Commons

Theriot, Edward and Bradbury, J. Platt, "Mesodictyon, A New Fossil Genus of the Centric Diatom Family Thalassiosiraceae from the Miocene Chalk Hills Formation, Western Snake River Plain, Idaho" (1987). USGS Staff -- Published Research. 254.

https://digitalcommons.unl.edu/usgsstaffpub/254

This Article is brought to you for free and open access by the US Geological Survey at DigitalCommons@University of Nebraska - Lincoln. It has been accepted for inclusion in USGS Staff -- Published Research by an authorized administrator of DigitalCommons@University of Nebraska - Lincoln. 


\title{
Mesodictyon, a new fossil genus of the centric diatom family Thalassiosiraceae from the Miocene Chalk Hills Formation, western Snake River Plain, Idaho
}

\author{
Edward Theriot ${ }^{1}$ and J. Platt Bradbury ${ }^{2}$ \\ 'Great Lakes Research Division, University of Michigan, Ann Arbor, Michigan 48109 \\ ${ }^{2}$ United States Geological Survey, Federal Center, Denver, Colorado 80225
}

\begin{abstract}
Three new centric diatom species assigned to a new genus are described from Miocene lacustrine deposits of Idaho. Species of the new genus, Mesodictyon, have the areola cribrum in the middle of the loculus, strutted processes and radiating, non-fasciculated striae. The strutted processes of $M$. magnum (diameter $60-150 \mu \mathrm{m}$ ) have long $(2-3 \mu \mathrm{m})$ tubular extensions. The strutted processes of $M$. fovis (diameter 14-80 $\mu \mathrm{m}$ ) are in distinct pits near the junction of the face and mantle. The valve face of $M$. undulatum (diameter $10-44 \mu \mathrm{m}$ ) is weakly tangentially undulate. Preliminary evidence indicates that Mesodictyon has a wide geographic distribution and may be a useful biostratigraphic marker.
\end{abstract}

\section{INTRODUCTION}

There is increasing interest in the freshwater fossil diatoms of western North America. One stimulus is the need for paleoecological indicators and biostratigraphic markers requiring reliably characterized freshwater diatoms. Another is the study of the phylogenetic history of freshwater diatoms. Cell wall ultrastructure has been shown to be extremely important for diatom taxonomy, and it is better understood for Holocene species than for older ones. This paper examines the morphology and systematics of three apparently extinct freshwater centric diatom species from upper Miocene deposits in the Snake River Plain of Idaho.

Bradbury and Krebs (1982) presented the first ultrastructural account of fossil diatoms from the Snake River Plain and tentatively classified four undetermined species from the upper Miocene Chalk Hills Formation in the genus Stephanodiscus Ehrenberg. This paper examines two of Bradbury and Krebs' species in greater detail, determining that they lack the characters of Stephanodiscus as diagnosed by Theriot and Kociolek (1986). Accordingly, the undetermined species are assigned to a new genus, Mesodictyon. The Greek root (middle-net) refers to the unique and diagnostic location of the cribrum in the areola.

The familial classification of the new genus is equivocal, but the species appear to be best placed in the family Thalassiosiraceae. This classification is consistent with a proposed restricted diagnosis of the family, one consistent with the recent history of Thalassiosiraceae systematics. The family is diagnosable, in our view, by only one character, the presence of at least one strutted process (or its homologue, the multistrutted process; Hasle and Syvertsen 1985).

\section{MATERIALS AND METHODS}

The lacustrine deposits of the Chalk Hills Formation in the western Snake River Plain, southwestern Idaho, accumulated during the late Miocene. Fossil mammals in the Chalk Hills Formation, initially considered Pliocene in age (Shotwell in Malde and Powers 1962), were later assigned to the Hemphillian or late Miocene (Berggren and Van Couvering 1974; Evernden et al. 1964). Fossil fish (Smith et al. 1982), fission track dating of volcanic ash (Kimmel 1979, 1982), and radiometric dates on basalts (Armstrong et al. 1975) also place these deposits in the late Miocene. The basaltic cinders of text-figure 1 are correlative with those of several nearby measured and dated sections (Kimmel 1979; Swirydczuk 1980), indicating an age greater than $8.7 \pm 1.0$ million years for the sampled sections of this study. Collectively, these estimates put the lacustrine deposition of the Chalk Hills Formation between approximately 10 and 7 million years ago. For the most part these deposits represent extensive lacustrine environments that occupied this system (Mabey 1976; Kimmel 1982).

Samples of diatomaceous silt collected from two localities representing the basal two-thirds of the Chalk Hills Formation are considered in this report. Two samples (USGS Denver diatom locality numbers 14 I $80-40 \mathrm{~N}$ and $-40 \mathrm{~T}$ ) came from the West Browns Creek locality, Owyhee County, Idaho. The location of this site is on the SW corner of the SW $1 / 4$, Section 2, T. $5 \mathrm{~S}, \mathrm{R} .1 \mathrm{~W}$, about $6 \mathrm{~km} \mathrm{~S} 35^{\circ} \mathrm{W}$ of the town of Oreana. This section consists of $64 \mathrm{~m}$ of sand, diatomaceous silt, and layers of volcanic ash and basaltic cinders. The samples were collected $34 \mathrm{~m}$ and $12 \mathrm{~m}$ below the top of the section (text-fig. 1).

A third sample (USGS Denver diatom locality number 14 I 80-39D) was collected from the Castle Creek locality, Owyhee County, Idaho, in the NW $1 / 4$ of the NE $1 / 4$, Section 9, T. $6 \mathrm{~S}, \mathrm{R}, 1 \mathrm{E}$, about $21 \mathrm{~km} \mathrm{~S} 69^{\circ} \mathrm{W}$ of the town of Grandview. This section of the Chalk Hills Formation consists of about $87 \mathrm{~m}$ of sand, basaltic cinder, volcanic ash, and diatomaceous silt. Sample 14 I 80-39D was collected $30.5 \mathrm{~m}$ below the top of the section and correlates to the Browns Creek section about $20 \mathrm{~m}$ below the level of sample 14 I 80-40N (text-fig. 1).

Microscopic observations were made at the University of Michigan and at the U.S. Geological Survey. At Michigan, light microscope (LM) slides were made of each sample by dispersing a small amount of untreated sample in distilled water on a coverslip and then mounting the dried smear in Hyrax. Samples were cleaned with hydrogen peroxide and potassium dichromate for scanning electron microscopy 
(SEM). Diatoms from a portion of each cleaned sample were concentrated with a series of nylon screens $(14 \mu \mathrm{m}, 56 \mu \mathrm{m}$, and $120 \mu \mathrm{m}$ ). Both sieved and unsieved subsamples were dried on coverslips glued to stubs, and the entire preparation was coated with approximately $15 \mathrm{~nm}$ of gold-palladium by sputter coating. Observations and photographs were made with an International Scientific Instruments DS-130 SEM operated at a range of accelerating voltages between 10-15 $\mathrm{kV}$. At the USGS, samples were cleaned in $100^{\circ} \mathrm{C}$ concentrated $\mathrm{HNO}_{3}$. The cleaned material was not sieved but was dried directly on coverslips mounted as above for each of LM and SEM. USGS SEM observations were made using a JEOL-35C SEM operated at $20 \mathrm{kV}$.

Anatomical terminology for diatoms is that of Anonymous (1975) and Ross et al. (1979). An exception is the term "fova" (Latin for "pit"), defined below.

\section{RESULTS}

Mesodictyon Theriot and Bradbury, n. gen.

Diagnosis: A genus of the family Thalassiosiraceae Lebour emend. Hasle. Distinguished from all other diatom genera known to have strutted processes by morphology of the loculate areolae, each having a cribrum inside the loculus and a foramen on both the internal and external valve surfaces.

Etymology: "Meso", Green for "middle", and "dictyon", neuter Greek noun meaning "net", refer to location of the cribrum in roughly the middle of the loculus.

Type species: Mesodictyon magnum Theriot, Bradbury and Krebs, n. sp.

Mesodictyon magnum Theriot, Bradbury and Krebs, n. sp.

Diagnosis: Distinguished from other known Mesodictyon species by its long, spine-like external extensions of strutted processes, and a cluster of several labiate processes on the valve mantle.

Holotype: A light microscopic preparation at the Academy of Natural Sciences of Philadelphia (ANSP A-G.C. 64255a).

Isotypes: LM preparations at ANSP (A-G.C. 64255b), U.S. Geological Survey, Denver (USGS; diatom locality 14 I 80 40T), Great Lakes Research Division, University of Michigan (GLRD; ECT 791). Unmounted materials collections at ANSP (5446), USGS (14 I 80-40T) and GLRD (ECT 791).

Type locality: Idaho, Owyhee Co., SW corner of the SW $1 / 4$, Section 2, T. $5 \mathrm{~S}, \mathrm{R} .1 \mathrm{~W}$, about $6 \mathrm{~km} \mathrm{~S} 35^{\circ} \mathrm{W}$ of the town of Oreana. (USGS diatom locality 14 I 80-40T.)

Etymology: "Magnum", neuter of "magnus", Latin for "large", refers to the large diameter of this species.

Morphological notes: Completely intact valves were rare. Large valves with diameters of 85-132 $\mu \mathrm{m}$ were observed for specimens with some part of the mantle intact (pl. 1, figs. 1-3). However, some fragments indicate a size range of about 60 $150 \mu \mathrm{m}$. Striae with 7-9 areolae in $10 \mu \mathrm{m}$ observed along a radius on the valve face. Where preserved, large spine-like processes occur about 2-4 $\mu \mathrm{m}$ apart at the juncture of the face and valve mantle.

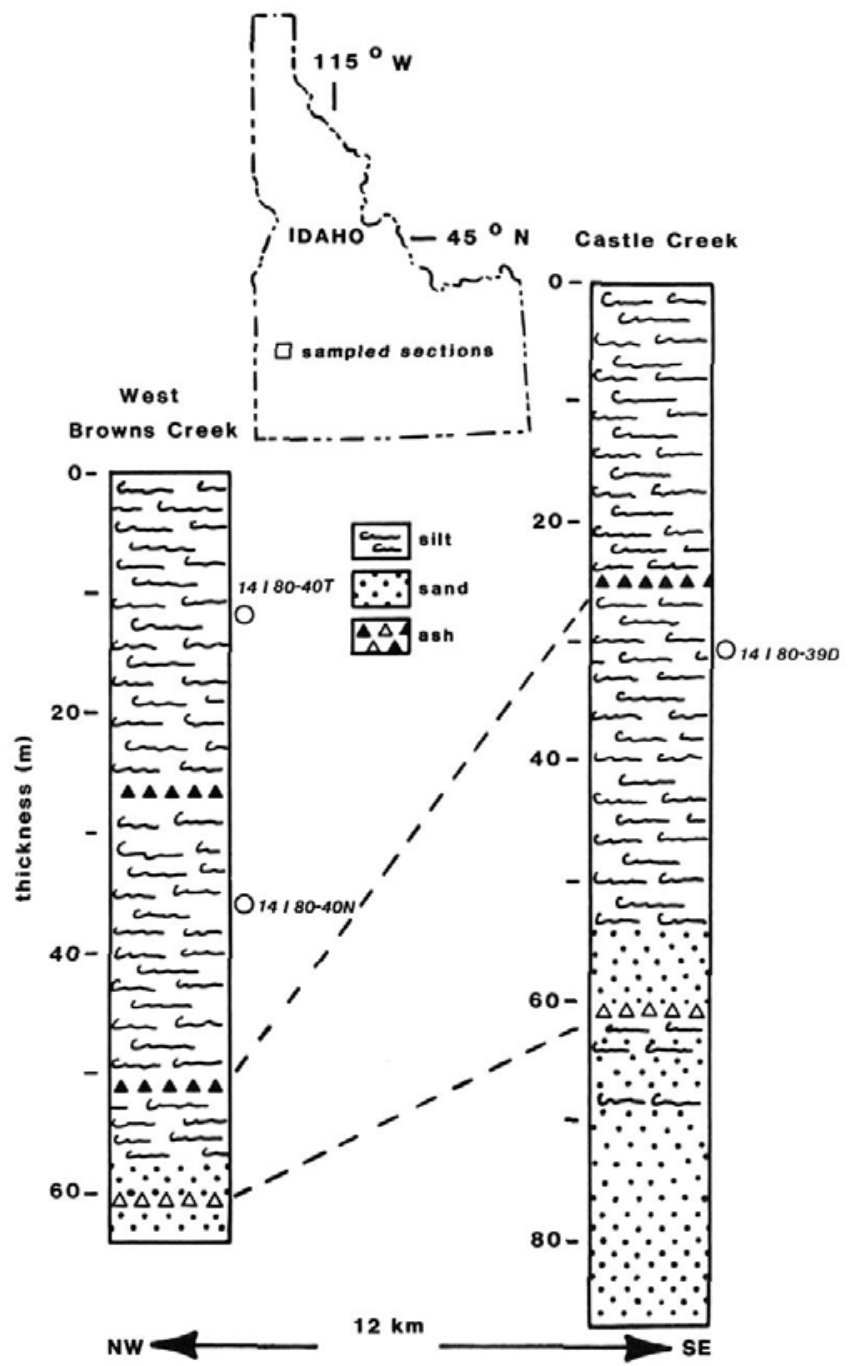

TEXT-FIGURE 1

Generalized stratigraphic sections of the basal two-thirds of the Chalk Hills Formation at West Browns Creek and Castle Creek, Owyhee County, Idaho, showing type localities of Mesodictyon magnum (14 I 80-40T), $M$. fovis (14 I 80-40N) and $M$. undulatum (14 I 80-39D). The stratigraphic correlation between the sections is based on basaltic (solid triangles) and rhyolitic (open triangles) volcanic ashes (Swirydczuk 1980).

In the SEM, these processes are observed to be hollow and their spacing and location at the junction of the face and margin corresponds to that of the strutted processes as seen on the interior (pl. 1, figs. 3, 4; pl. 2, fig. 2). We interpret these processes to be the external expression of the strutted process. Internally each strutted process occurs in a small depression which we call a fova, the Latin word for "pit". The strutted processes have two satellite pores and occasionally are "twinned" (pl. 2, figs. 1, 4, 5).

From 4-7 labiate processes (LP) occur on each of 15 valves observed in the type material. They are arranged in a single loose cluster on the mantle (pl. 1, figs. 1, 2, 4; pl. 2, figs. 1, $2,4)$. Internally, each occupies a hyaline region of the mantle. Externally, each appears as a large pore in a hyaline field on 
the mantle, visible even in LM. It could be that there was some spine-like extension of the LP as there is for the strutted process, but we believe that there was none on the living cell. Although strutted processes left clear evidence of their extension, no such evidence was observed for the LP.

An areola of the mantle has a flat, perforated cribrum nearer to the internal valve surface than to the external and the sides of the loculus are nearly parallel without marked constrictions at the internal and external foramina (pl. 2, figs. 3, 5). In contrast, a valve face areola has a constricted external foramina opening into a wide chamber with concave walls (pl. 2, fig. 3). Inside this chamber is a perforated cribrum domed towards the valve exterior. From the point of attachment of the cribrum, the walls of the loculus flair and form a wide internal foramen.

Notes on presumed depositional environment as indicated by associated siliceous microfossils: Mesodictyon magnum and Melosira $\mathrm{cf}$. islandica dominated the preserved assemblage. The gross morphology of each is typical of modern planktonic centric diatoms. However, species of the diatom genera Diatoma, Fragilaria, Epithemia, Navicula, Achnanthes, Amphora, Epithemia and Cocconeis were proportionately common to rare indicating the depositional environment was in or near a shallow area. Chrysophycean cysts and two undescribed species of Mesodictyon (each less than $12 \mu \mathrm{m}$ in diameter) were rare.

\section{Mesodictyon fovis Theriot, Bradbury and Krebs, n. sp.}

Diagnosis: Distinguished from other known species by the presence of strongly domed medial cribra in the loculate areolae of both the face and mantle, by the presence of siliceous branching occlusions of the external foramina, and by strongly developed fovae in each of which is located a strutted or labiate process.

Synonyms: Stephanodiscus sp., Bradbury and Krebs (1982) plates 5 and 6 .

Holotype: LM preparation at ANSP (A-G.C. 64256a).

Isotypes: LM preparations at ANSP (A-G.C. 64256b), USGS (Denver; 14 I 80-40N), GLRD (ECT 786). Unmounted material at ANSP (5447), USGS (Denver; 14 I 80-40N) and GLRD (ECT 786).
Type locality: Idaho, Owyhee Co., SW corner of the SW 1/4, Section 2, T. $5 \mathrm{~S}, \mathrm{R} .1 \mathrm{~W}$, about $6 \mathrm{~km} \mathrm{~S} 35^{\circ} \mathrm{W}$ of the town of Oreana. (USGS 14 I 80-40N.)

Etymology: "Fovis", ablative of "fova", Latin meaning "having pits", referring to the characteristic structure as seen in SEM.

Morphological notes: The heavily silicified valves are circular with radiating rows of areolae (pl. 3, figs. 1-4; pl. 4, fig. 1; pl. 5, fig. 1). Observed diameters range from $14-80 \mu \mathrm{m}$ with 3.5-7.5 areolae per $10 \mu \mathrm{m}$ along a radius on the valve face. A thickened, knob-like papillus occurs near the center of the valve. A depression occurs next to it, apparently marking the papillus of the sibling valve. The papillus and depression are best observed on smaller valves (pl. 3, fig. 3), and have little external evidence in larger valves. The papillus and depression have obvious internal expression in both large and small valves (pl. 5, fig. 5).

Each loculate areola has two morphologically distinct types of occlusions. The external occlusions are formed by branching inward extensions of the areola wall (pl. 3, fig. 4), but the medial occlusions are virtually identical in appearance to the medial cribra of the valve face of $M$. magnum (pl. 3, fig. 5; pl. 4, fig. 1; pl. 5, fig. 1). We consider the medial cribra in these taxa homologous and the external cribrum an evolutionary novelty diagnosing $M$. fovis. Unlike those of $M$. magnum, the medial cribra of the mantle areolae are not flat, but are domed towards the external surface (pl. 4, fig. 1). The internal foramina are ringed by ridges of silica (pl. 5, figs. 1$5)$.

Three types of processes occur on each valve. Spines or their remnants occur on about every fourth to sixth hyaline interstriae (pl. 3, figs. 3, 4; pl. 4, fig. 1). Spine bases of specimens in good condition indicate that spines are solid (pl. 3, fig. 4). There appears to be a shallow depression in the center of each spine base in heavily eroded specimens (pl. 3, fig. 3). We now regard the depressions as preservation artifacts, having observed a similar phenomenon in living Stephanodiscus species which are known to have solid spines. A submarginal ring of strutted processes and a single labiate process were observed on each valve (pl. 5, figs. 1-5). Strutted processes occur one per fova and have two satellite pores; several areolae also occupy each fova (pl. 5, figs. 1-4). The fova in

\section{PLATE 1}

1-4 Mesodictyon magnum Theriot, Bradbury and Krebs, n. sp.

From USGS Denver 14 I 80-40T. 1, LM, scale is 10 $\mu \mathrm{m}$ : $1 \mathrm{a}-\mathrm{c}$, same specimen at three different foci; $1 \mathrm{a}$, focus on mantle, labiate processes (arrows); $1 \mathrm{~b}$, focus on striae; 1c, focus on central area. 2-4, SEM: 2a, outside whole valve, labiate processes (arrows), scale is $10 \mu \mathrm{m} ; 2 \mathrm{~b}$, detail of labiate process external pores (arrow) and strutted process (S), scale is $1 \mu \mathrm{m}$. 3a, exterior of whole valve with exterior tubes of strutted processes (S), scale is $10 \mu \mathrm{m} ; 3 \mathrm{~b}$, detail of strutted process, scale is $1 \mu \mathrm{m}$. 4 , fragment of mantle region with labiate process external pores (arrow) and bases of strutted processes (S), scale is $3 \mu \mathrm{m}$. 


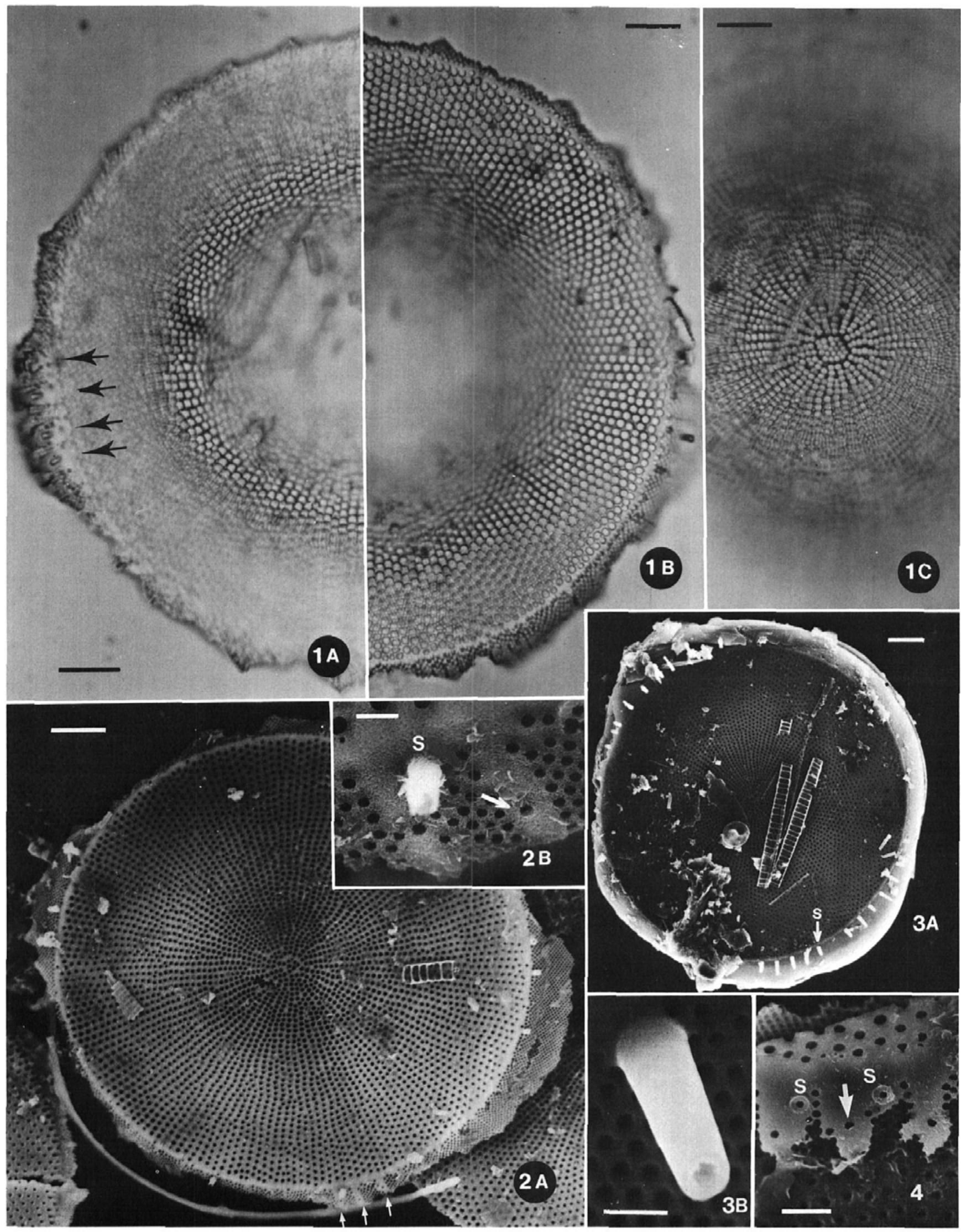


which the labiate process occurs is shallower than that of a strutted process. The external expression of the labiate process is a large pore without a tube, that of the strutted process is a small pore in a small mound of silica immediately subtending a spine (pl. 3, figs. 3, 4). Strutted and labiate processes occur $0-6$ areolae from the margin, depending on the diameter of the valve (pl. 3, figs. 3-4; pl. 5, figs. 1-4). No details of the cingulum are known, other than the apparent existence of at least four bands per valve.

Notes on presumed depositional environment as indicated by associated siliceous microfossils: Mesodictyon fovis and a small (4-12 $\mu \mathrm{m}$ diameter) undescribed, filamentous species of $\mathrm{Me}$ sodictyon dominated the assemblage. The gross morphology of each species is typical of modern planktonic centric diatoms. The benthic diatom genera Achnanthes and Gomphonema were the next most commonly observed diatoms. The rare proportionate abundance of these and other benthic diatoms indicates a relatively deep depositional environment, probably distant from extensive shallow areas.

Mesodictyon undulatum Theriot, Bradbury and Krebs, n. sp.

Diagnosis: Distinguished from other known Mesodictyon species by the presence of a weakly tangentially undulate valve face.

Synonyms: Stephanodiscus sp., Bradbury and Krebs (1982), plate 4 .

Holotype: LM preparation at ANSP (A-G.C. 64257a).

Isotypes: LM preparations at ANSP(A-G.C. 64257b), USGS, Denver (14 I 80-39D), GLRD (ECT 782). Unmounted material at ANSP (5448), USGS (14 I 80-39D), and GLRD (ECT 782).

Etymology: "Undulatum", neuter of "undulatus", Latin for "wavy", referring to characteristic morphology of the valve face.

Type locality: Idaho, Owyhee Co., NW 1/4 of NE 1/4, Section 9 , T. $6 \mathrm{~S}$, R. $1 \mathrm{E}$, about $21 \mathrm{~km} \mathrm{~S} 69^{\circ} \mathrm{W}$ of the town of Grandview. (USGS 14 I 80-39D.)

Morphological notes: Diameters of $10-44 \mu \mathrm{m}$ were observed. Striae radiate from the center, with 5-11 areolae in $10 \mu \mathrm{m}$ along a radius (pl. 6, figs. 1-3). Areolae cribra on the mantle are flat and those of the valve face are domed towards the exterior, more similar to that of $M$. magnum than to $M$. fovis (pl. 6, figs. 4, 5).

Spines are visible in some specimens; SEM observations suggest that they are broken or eroded on other specimens. Openings of strutted processes occur below each spine. Internally each strutted process has two satellite pores and a small occlusion extending from each side of the central tube (pl. 6, fig. 4). The labiate process occurs just inside the ring of strutted processes, more or less evenly spaced between two of the latter, and is associated with the opening of the first girdle band (pl. 6, figs. 4, 5). Even with the aid of these landmarks, external expression of the labiate process was never clearly recognized. It is our opinion that the labiate process had no external tubular extension in the living condition and its external expression is a nondescript areolalike pore.

Certain details of the cingulum can be deduced from observations on four specimens, two each in internal and external views. The valvocopula and copula appear to be punctate, with at least one and perhaps as many as three pleurae (pl. 6 , fig. 1). The first girdle band opening is to the viewer's right of the labiate process in upright external view (pl. 6, fig. 5).

Notes on presumed depositional environment as indicated by associated siliceous microfossils: $M$. undulatum dominated the preserved assemblage and has the general appearance of modern planktonic centric diatoms. Fragments of long, thin planktonic forms of Synedra spp. were the only other common diatom remains observed. Nitzschia, Fragilaria, Melosira and Epithemia were rarely observed. This indicates that the depositional environment was more like that of $M$. fovis than $M$. magnum, i.e. the assemblage indicates a deep, planktonic environment removed from an immediate source of benthic diatoms.

\section{DISCUSSION}

These results indicate the need for revision of generic concepts in the Thalassiosiraceae and for continued detailed review of North American freshwater fossil centric diatoms. Mesodictyon fovis and $M$. undulatum were originally tentatively classified in Stephanodiscus (Bradbury and Krebs 1982). Theriot and Kociolek (1986) recently reviewed current con-

PLATE 2

1-5 Mesodictyon magnum Theriot, Bradbury and Krebs, n. sp.

From USGS Denver 14 I 80-40T. 1-5, SEM. 1a, interior of whole valve, two labiate processes are indicated by arrow, scale is $10 \mu \mathrm{m}$; $1 \mathrm{~b}$, detail of labiate processes, note strutted process in fova (S), scale is 1 $\mu \mathrm{m}$. 2, labiate process field with strutted processes indicated by arrows, scale is $3 \mu \mathrm{m}$. 3a, perspective of mantle (large arrow) and face (small arrow) areolae, scale is $1 \mu \mathrm{m} ; 3 \mathrm{~b}$, mantle areola, cribrum at arrow, scale is $.4 \mu \mathrm{m} ; 3 \mathrm{c}$, domed cribrum of face areola, scale is .2 $\mu \mathrm{m}$. 4 , detail of labiate and strutted processes, strutted process on left is "normal", that on right has two central pores, scale is .7 $\mu \mathrm{m}$. 5 , detail of "twinned" strutted processes, one central pore with two satellite pores and a second with one satellite pore, note cribrum of mantle areola to the upper right, scale is .2 $\mu \mathrm{m}$. 


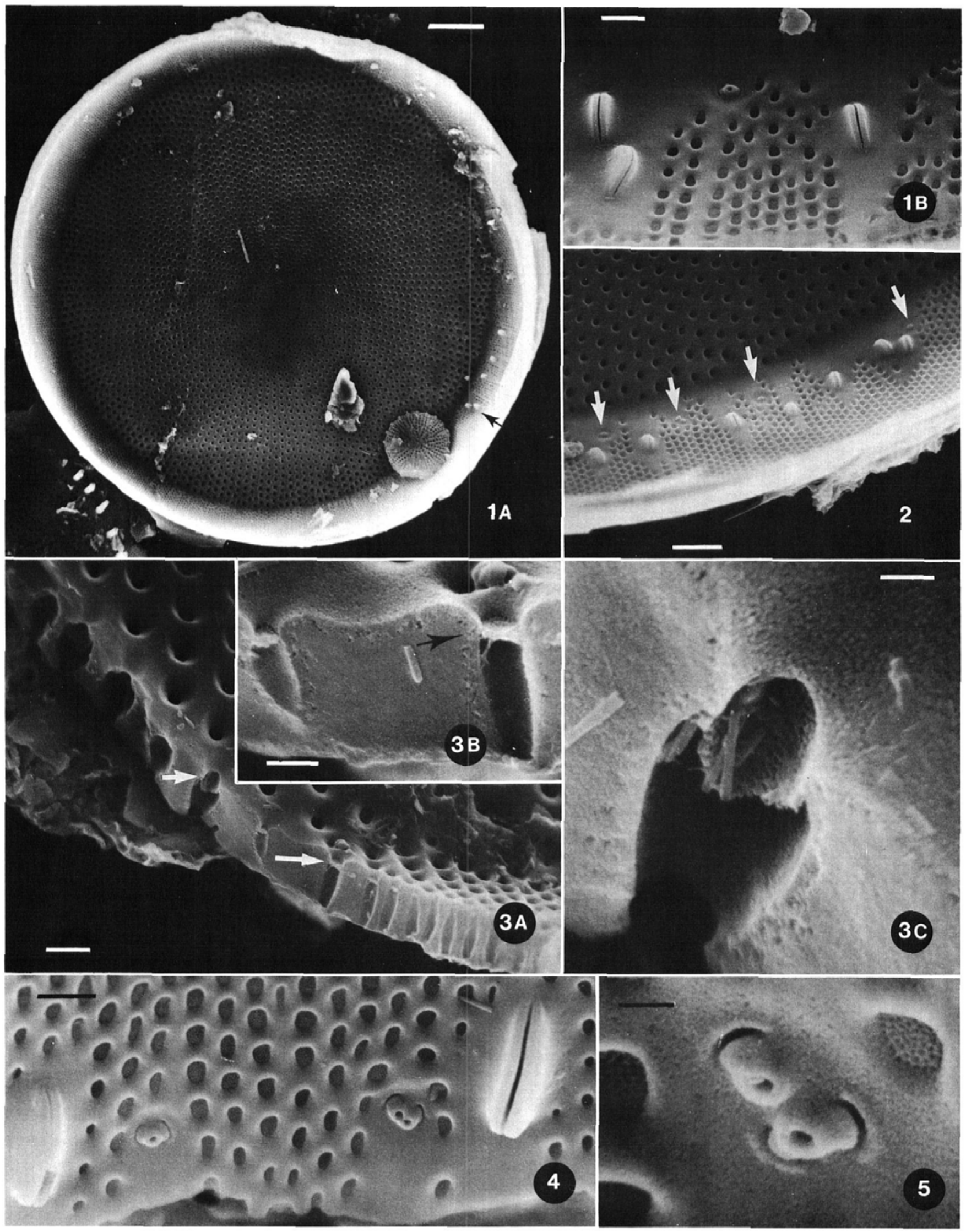


cepts of Stephanodiscus and the similar genus Cyclostephanos Round, proposing that Stephanodiscus is best diagnosed as having internally domed cribra on the mantle and valve face, and an external spine-like extension of the labiate process. These criteria are consistent with the type species of Stephanodiscus (Theriot and Stoermer 1981; Håkansson and Locker 1981; Round 1981), are unique to Stephanodiscus vis-à-vis Cyclostephanos and ignore characters (radiating striae, etc.) that are also shared by other genera. The species described here lack internally domed mantle cribra and spine-like labiate processes and so cannot be placed in our concept of Stephanodiscus. Moreover, they share a feature not shared by any other genus with strutted processes, namely medial cribra, and we create the genus Mesodictyon to include them.

Their higher level classification is equivocal. Strutted processes only occur in species of the family Thalassiosiraceae; internal cribra and external foramina are also considered characteristic of the family (e.g. Hasle 1973; Simonsen 1979; Johansen and Fryxell 1985). Although the three Mesodictyon species described here all have strutted processes, they also have medial cribra and one has external, cribrum-like occlusions. The former condition is not characteristic of any other centric genus with which we are familiar, whereas external cribra are characteristic of such genera as Actinocyclus and Coscinodiscus which lack strutted processes and are not currently classified in the Thalassiosiraceae (e.g. Fryxell and Hasle 1974; Hasle 1977; Fryxell and Semina 1981; Bradbury and Krebs 1982; Bradbury 1984).

This could be resolved by proposing a new family level taxon or arguing that one character or the other should be more heavily weighted in the existing classification. We believe that a restricted diagnosis of the Thalassiosiraceae is appropriate (regardless of the Idaho species), and that such a restricted diagnosis is also compatible with classification of the Idaho species within a genus of the Thalassiosiraceae. Only the strutted process is restricted to taxa currently placed in the Thalassiosiraceae. Other characters cited as characteristic of the Thalassiosiraceae do occur in species of the family, of course. However, except for the strutted process, they are of limited value in diagnosis of the family because they also occur outside of the family. Thus we place Mesodictyon in the Thalassiosiraceae, in spite of cribra location, because it possesses strutted processes.

Mesodictyon seems to be an extinct genus. Its true diversity and its geographic and geologic distribution remain open for further research. Preliminary investigations have revealed at least four more undescribed species from the Chalk Hills Formation which overlap in time with the described species. Preliminary LM observations also indicate that Mesodictyon is widespread in Miocene deposits of California, Idaho, Nevada and Oregon. It may even have a broader geographic distribution than North America. G. Khursevich (personal commun. to JPB) sent a single SEM picture of a diatom identified as Stephanodiscus nemanensis Khursevich that bears a strong overall resemblance to Mesodictyon from a reportedly lower Pliocene deposit in Byelorussia.

Diatoms can be reliable paleolimnological indicators, but conclusions based on only three samples are necessarily tenuous for a system as extensive geographically and temporally as the Miocene Chalk Hills lake. Kimmel (1982) reviewed competing hypotheses on the formation of the Chalk Hills lake and suggested that it may have drained during the late Miocene. Our preliminary data do not contradict this. The type samples of the two older species, $M$. fovis and $M$. undulatum, are indicative of deeper habitats far from shallow water relative to that of the younger M. magnum. Results of detailed biostratigraphic analysis (W. Krebs in prep.) of a wider geographical and temporal range of samples may allow more detailed analysis of the formation and changes in the Chalk Hills lacustrine system.

The species described here are relatively large for freshwater centric diatoms and are easily distinguished in LM, making them of potential use to biostratigraphers. Species categories were originally created informally in the LM by W. Krebs (personal commun.). While SEM observations were indispensable in classifying the species, they only confirmed and expanded his original species-level diagnoses. If our notion that the genus is extinct and widespread is true, there is (unexplored) potential for Mesodictyon species as world-wide biostratigraphic markers in paleolacustrine systems.

\section{ACKNOWLEDGMENTS}

Dr. William Krebs (AMOCO) generously donated material and observations on the diagnosis of species, especially at the light microscope level, and so is included as an author of the three species. Mr. Michael Evetts and Dr. Krystyna Swirydczuk assisted in sample collection. Dr. C. A. Repenning critically reviewed an early manuscript. Contribution no. 462 of the University of Michigan Great Lakes Research Division was supported by N.S.F. grant BSR-8507709 and a Jessup-McHenry Fellowship from the Academy of Natural

\section{PLATE 3}

1-5 Mesodictyon fovis Theriot, Bradbury and Krebs, n. sp. From USGS Denver 14 I 80-40N. 1-2, LM; 3-5, SEM. 1 , large specimen, scale is $5 \mu \mathrm{m}$. 2, small specimen, scale is $5 \mu \mathrm{m}$. 3, small specimen, with papillus and corresponding depression in central area and marginal strutted processes (S) and spines (arrow), about $45^{\circ}$ tilt, scale is $3 \mu \mathrm{m} .4 \mathrm{a}$, large specimen with labiate process opening next to a spine (arrow), scale is $5 \mu \mathrm{m} ; 4 \mathrm{~b}$, detail of mantle, the labiate process opening and a strutted process opening below a spine base, scale is $1 \mu \mathrm{m}$. 5 , areolae of the valve face, break along a single stria viewed from the exterior, scale is $1 \mu \mathrm{m}$. 


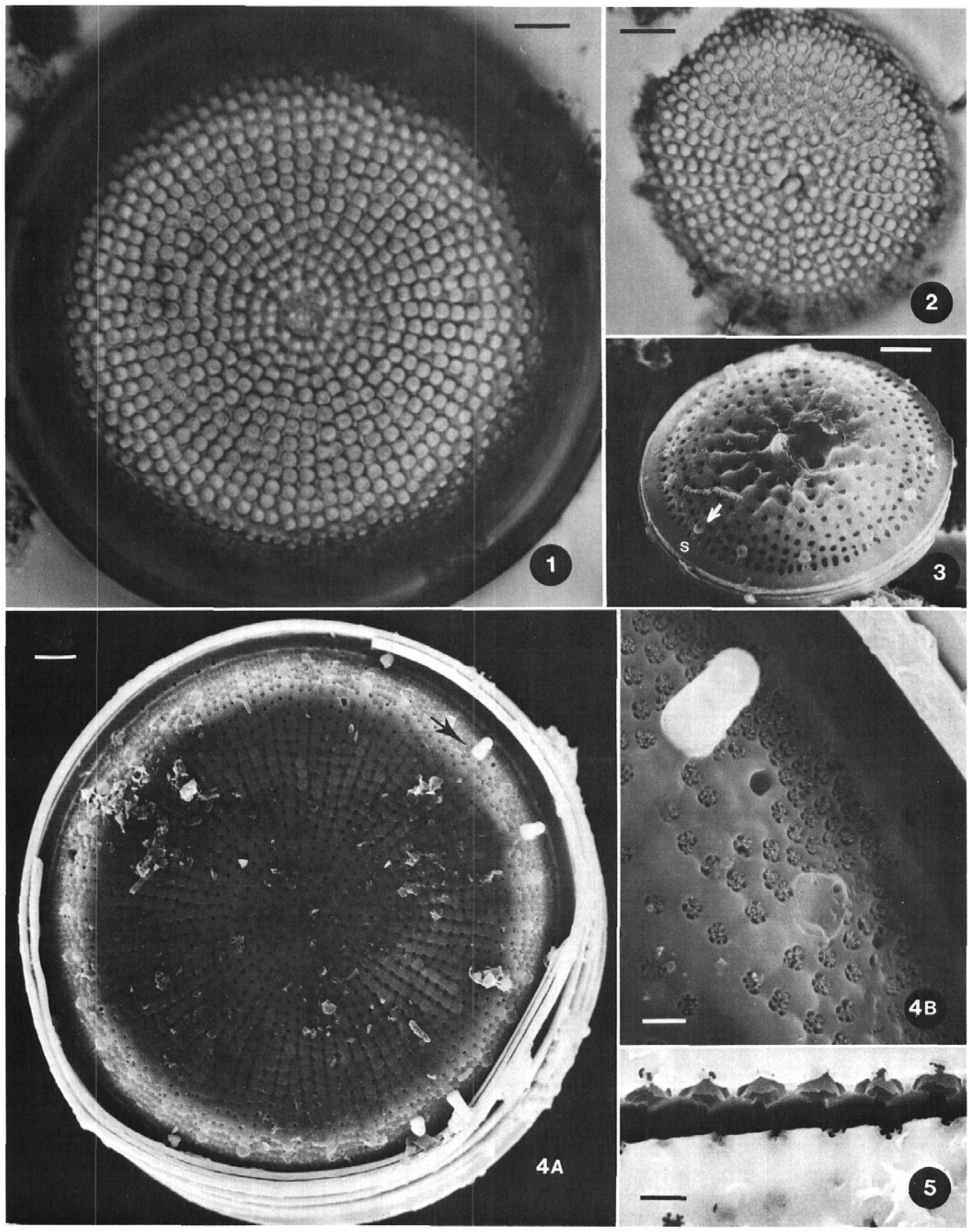




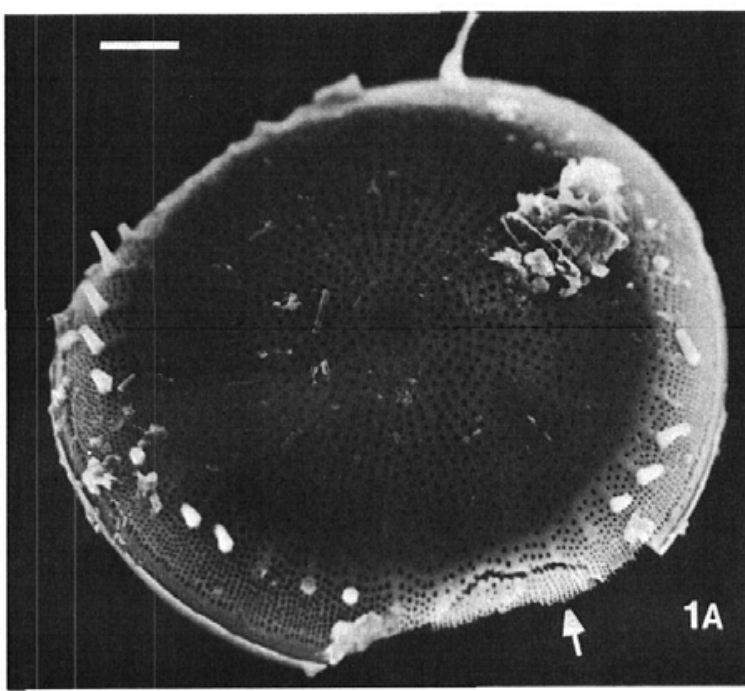

$1 A$

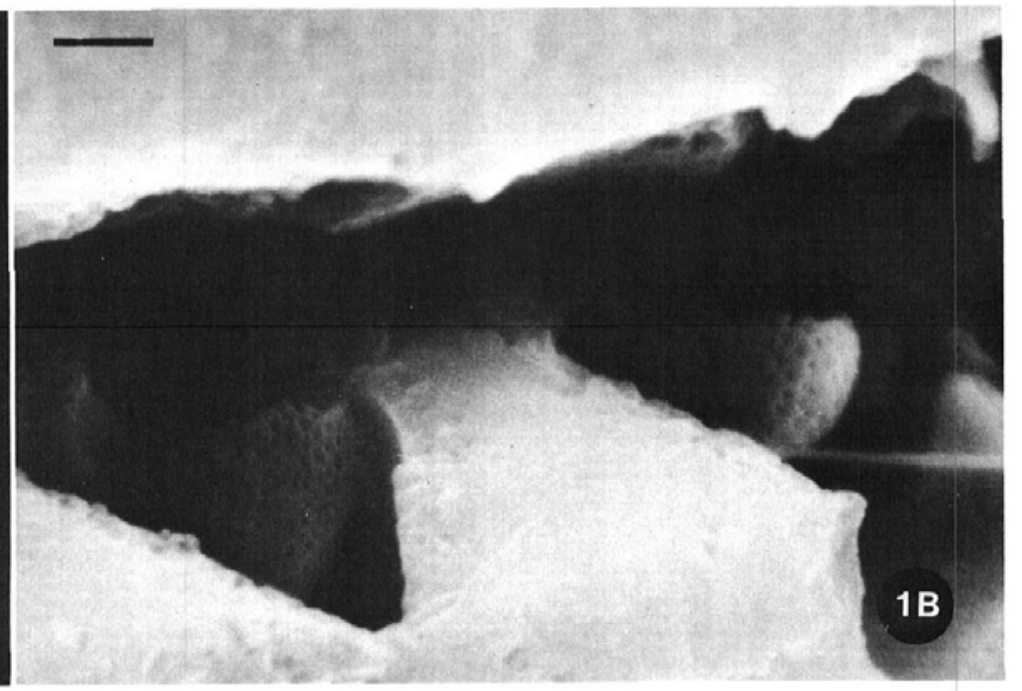

PLATE 4

1 Mesodictyon fovis Theriot, Bradbury and Krebs, n. sp. From USGS Denver 14 I 80-40N. 1a, whole valve with broken mantle (arrow), scale is $10 \mu \mathrm{m} ; 1 \mathrm{~b}$, detail of ar- eolae on mantle viewed through the broken mantle, scale is $2 \mu \mathrm{m}$.
Sciences of Philadelphia to ET, and by the U.S. Geological Survey Climate Change Program.

\section{REFERENCES}

ANONYMOUS, 1975. Proposals for a standardization of diatom terminology and diagnoses. Beihefte zur Nova Hedwigia, 53:322354.

ARMSTRONG, R. L., LEEMAN, W. P., and MALDE, H. E., 1975. $\mathrm{K}$-Ar dating, Quaternary and Neogene volcanic rocks of the Snake River Plain, Idaho. American Journal of Science, 275:225-251.

BERGGREN, W. A., and VAN COUVERING, J. A., 1974. The Late Neogene, biostratigraphy, geochronology, and paleoclimatology of the last 15 million years in marine and continental sequences. Paleogeography, Paleoclimatology, Paleoecology, 16:1216.

BRADBURY, J. P., 1984. Fossil Actinocyclus species from freshwater Miocene deposits in China and the United States. 7th Symposium on Recent and Fossil Diatoms, Philadelphia 1982, Proceedings (Mann, D.G., Ed.). Koenigstein: O. Koeltz, 157-171.
BRADBURY, J. P., and KREBS, W. N., 1982. Neogene and Quaternary lacustrine diatoms of the western Snake River Basin IdahoOregon, USA. Acta Geologica Academiae Scientarium Hungaricae, 25:97-122.

EVERNDEN, J. F., SAVAGE, D. E., CURTIS, G. H., and JAMES, J. T., 1964. Potassium-argon dates and the Cenozoic mammalian chronology of North America. American Journal of Science, 262: 145-198.

FRYXELL, G. A., and HASLE, G. R., 1974. Coscinodiscineae: some consistent patterns in diatom morphology. Beihefte zur Nova Hedwigia, 45:69-84.

FRYXELL, G. A., and SEMINA, H. J., 1981. Actinocyclus exiguus sp. nov. from the southern parts of the Indian and Atlantic Oceans. British Phycological Journal, 16:441-448.

HÅKANSSON, H., and LOCKER, S., 1981. Stephanodiscus Ehrenberg 1846, a revision of the species described by Ehrenberg. Nova Hedwigia, 35:117-150.

HASLE, G. R., 1973. Thalassiosiraceae, a new diatom family. Norwegian Journal of Botany, 20:67-69.
1-5 Mesodictyon fovis Theriot, Bradbury and Krebs, n. sp. From USGS Denver 14 I 80-40N. 1-5, SEM. 1a, whole valve with labiate process (arrow), scale is $5 \mu \mathrm{m} ; 1 \mathrm{~b}$, detail of broken mantle with break through labiate (arrow) and strutted (S) processes, scale is $1 \mu \mathrm{m} .2$, mantle of $61 \mu \mathrm{m}$ specimen, scale is $1 \mu \mathrm{m}$. 3, mantle of $38 \mu \mathrm{m}$ specimen, scale is $1 \mu \mathrm{m}$. 4 , mantle of $22 \mu \mathrm{m}$ specimen, scale is $1 \mu \mathrm{m}$. 5, detail of central area, structure related to central area papillus and depression (cf. pl. 3, fig. 3), scale is .5 $\mu \mathrm{m}$. 

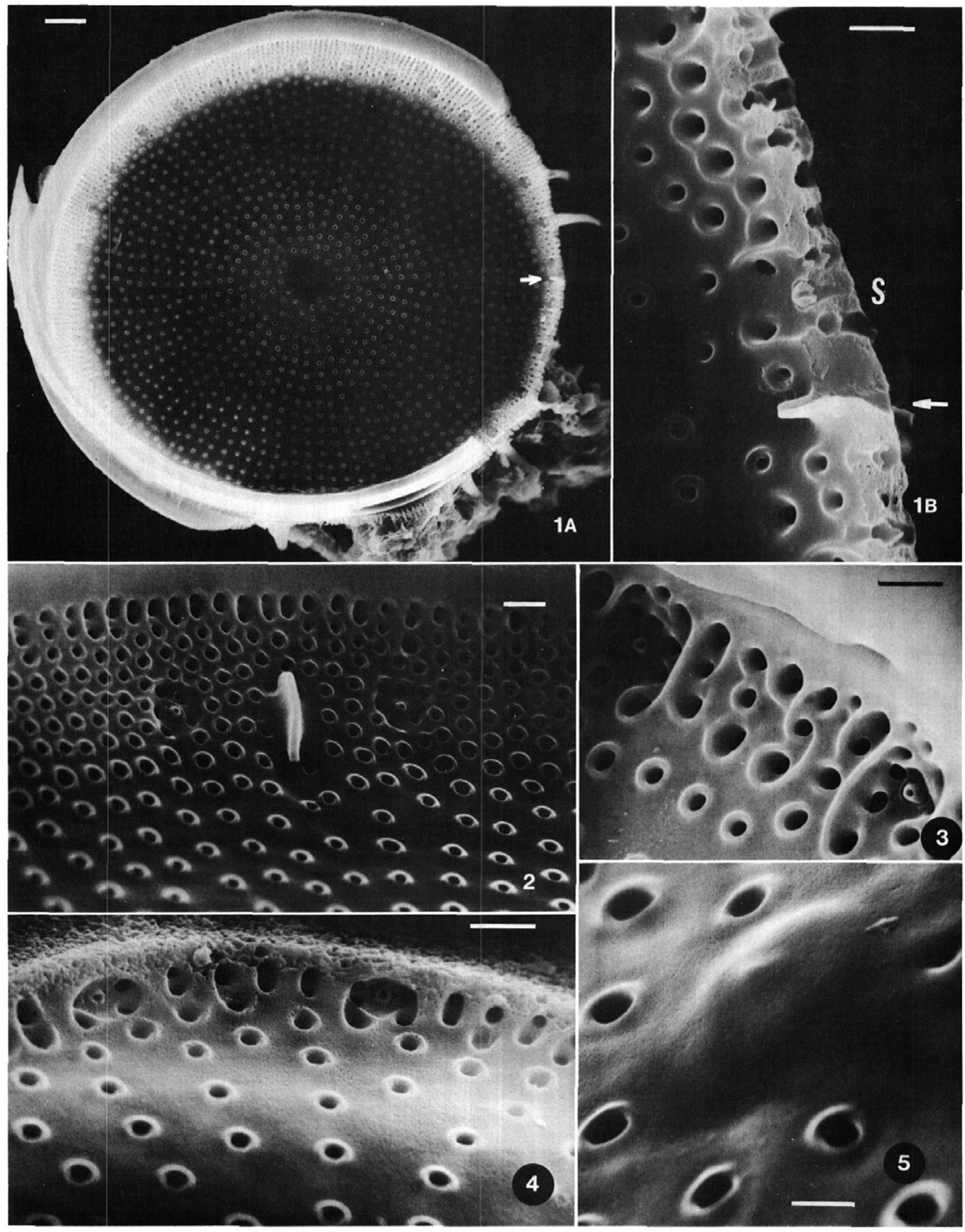
1977. Morphology and taxonomy of Actinocyclus normanii fo. subsalsa (Bacillariophyceae). Phycologia, 16:321-328.

HASLE, G. R., and SYVERTSEN, E. E., 1985. Thalassiosiropsis, a new diatom genus from the fossil records. Micropaleontology, 31 : 82-91.

JOHANSEN, J. R., and FRYXELL, G. A., 1985. The genus Thalassiosira (Bacillariophyceae): studies on species occurring south of the Antarctic Convergence Zone. Phycologia, 24:155-179.

KIMMEL, P. G., 1979. Stratigraphy and paleoenvironments of the Miocene Chalk Hills Formation and Pliocene Glenns Ferry Formation in the Western Snake River Plain, Idaho. Ph.D. Dissertation, University of Michigan, $331 \mathrm{pp}$.

1982. Stratigraphy, age and tectonic setting of the MiocenePliocene lacustrine sediments of the western Snake River Plain, Oregon and Idaho. In: Bonnichsen, B., and Breckenridge, R. M., Eds., Cenozoic geology of Idaho. Idaho Bureau of Mines and Geology Bulletin, 26:559-578.

MABEY, D. R., 1976. Interpretation of a gravity profile across the western Snake River Plain. Geology, 1:53-55.

MALDE, H. E., and POWERS, H. A., 1962. The upper Cenozoic stratigraphy of Western Snake River Plain, Idaho. Geological Society of America Bulletin, 73:1197-1220.

ROSS, R., COX, E. J., KARAYEVA, N. I., MANN, D. G., PADDOCK, T. B. B., SIMONSEN, R., and SIMS, P. A., 1979. An amended terminology for the siliceous components of the diatom cell. Beihefte zur Nova Hedwigia, 64:513-533.

ROUND, F. E., 1981. The diatom genus Stephanodiscus: an electron microscopic view of the classical species. Archiv für Protistenkunde, 124:455-470.

SIMONSEN, R., 1979. The diatom system: ideas on phylogeny. Bacillaria, 2:9-71.

SMITH, G. R., SWIRYDCZUK, K., KIMMEL, P. G., and WILKINSON, B. H., 1982. Fish biostratigraphy of late Miocene to Pleistocene sediments of the western Snake River Plain, Idaho. In: Bonnichsen, B., and Breckenridge, R. M., Eds., Cenozoic geology of Idaho. Idaho Bureau of Mines and Geology Bulletin, 26: 519-541.

SWIRYDCZUK, K., 1980. Sedimentology of the Pliocene Glenns Ferry oolite and its stratigraphic setting in the Western Snake River Plain. Ph.D. Dissertation, University of Michigan, $247 \mathrm{pp}$.

THERIOT, E., and KOCIOLEK, J. P., 1986. Two new Pliocene species of Cyclostephanos (Bacillariophyceae) with comments on the classification of the freshwater Thalassiosiraceae. Journal of Phycology, 22:121-128.

THERIOT, E., and STOERMER, E. F., 1981. Some aspects of morphological variation in Stephanodiscus niagarae (Bacillariophyceae). Journal of Phycology, 17:64-72.

Manuscript received July 24, 1986.

Manuscript accepted January 13, 1987.
1-4 Mesodictyon undulatum Theriot, Bradbury and Krebs, n. sp.

From USGS Denver 14 I 80-39D. 1-2, 4-5, SEM; 3, LM. 1, exterior with spines and strutted processes (S), central area slightly tangentially undulate, scale is 2 $\mu \mathrm{m}$. $2 \mathrm{a}$, interior with labiate process (arrow), scale is $5 \mu \mathrm{m} ; 2 \mathrm{~b}$, detail of mantle area, strutted process (arrow), scale is $1 \mu \mathrm{m} ; 2 \mathrm{c}$, detail of strutted process of $2 b$ and of mantle areola cribra, scale is .1 $\mu \mathrm{m} .3$, valve view with central area out of focus due to tangential undulation of valve face, scale is $5 \mu \mathrm{m}$. 4a, broken valve with region of exposed areola cribra between arrows, scale is $3 \mu \mathrm{m}$; $4 \mathrm{~b}$, detail of face areolae, scale is $.5 \mu \mathrm{m}$. 5 , relative positions of labiate process and opening of valvocopula (VC) covered by ligula (L) of copula (C), scale is $1 \mu \mathrm{m}$. 

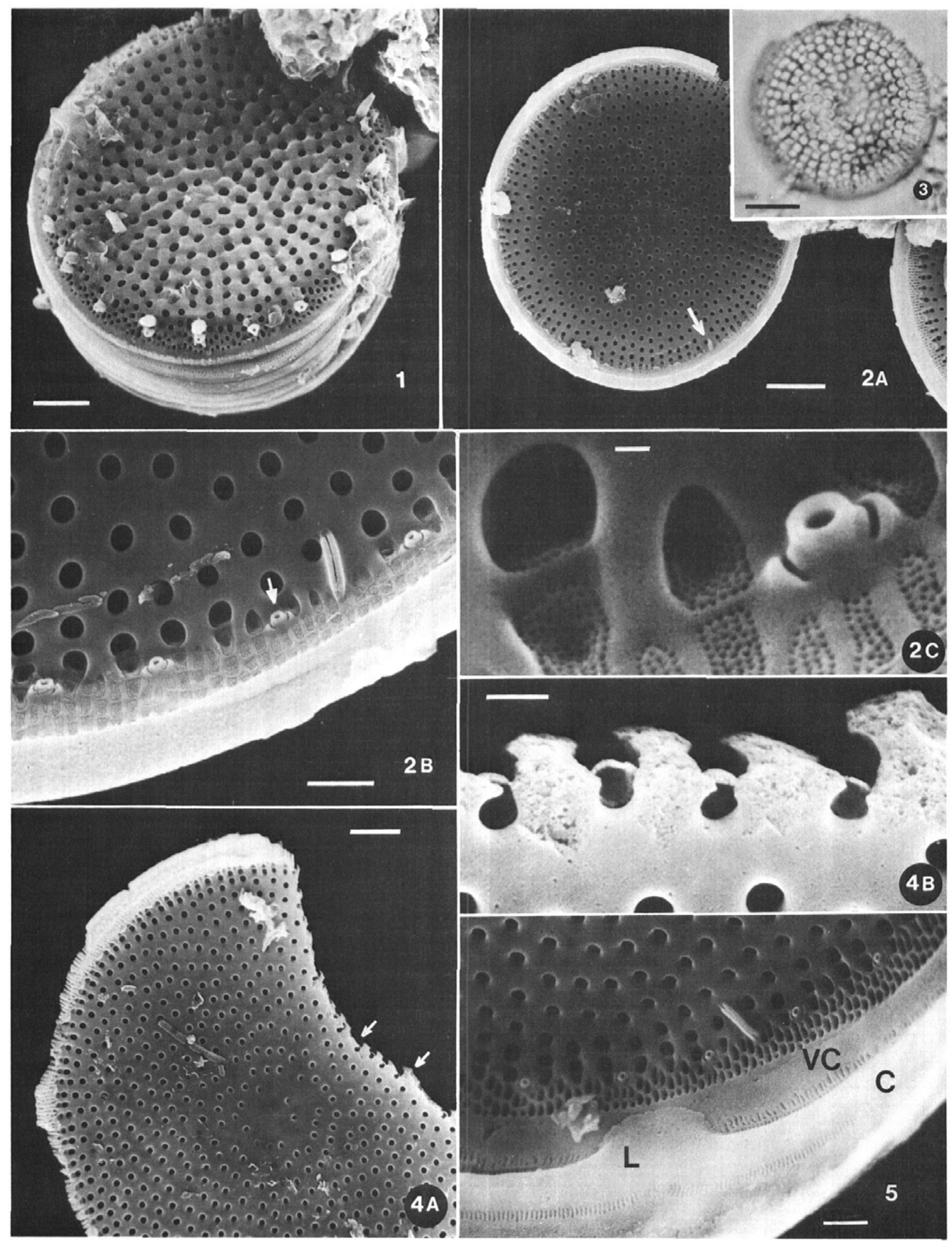